\title{
Two endophytic bacterial strains modulate Mn oxidation and accumulation in the wetland plant Suaeda salsa pall
}

\author{
Guoyan Zhao • Junhui Cheng • Ningning Sun • \\ Changle Ma $\cdot$ Meixue Dai
}

Received: 17 July 2018 / Accepted: 28 February 2019/Published online: 9 March 2019

(C) The Author(s) 2019

\begin{abstract}
Aims Wetlands play vital roles as sinks for metal contaminants. Some wetland plants accumulate manganese (Mn) oxides in the black biofilm around roots and rhizomes, although the underlying mechanism is still unclear. Our aim is to determine the role of endophytic bacteria in the formation of Mn deposits in the wetland plant Suaeda salsa Pall. as well as the underlying chemical and molecular mechanisms.

Methods Manganese-oxidizing endophytic bacteria were isolated with leucoberbeline blue (LBB) and further identified via the phylogenetic analysis. The Mn
\end{abstract}

\footnotetext{
Highlights

- Two endophytic Mn-oxidizing bacterial strains promote Mn accumulation in Suaeda salsa.

- Diverse Mn oxides are produced by these endophytic bacterial strains.

- Mn oxidation is catalyzed by hydrogen peroxide-detoxifying enzymes.
}

Guoyan Zhao and Junhui Cheng contributed equally to this work.

Responsible Editor: Juan Barcelo.

Electronic supplementary material The online version of this article (https://doi.org/10.1007/s11104-019-04019-8) contains supplementary material, which is available to authorized users.

G. Zhao $(\bowtie) \cdot J$. Cheng $\cdot$ N. Sun $\cdot$ C. Ma $\cdot$ M. Dai College of Life Science, Shandong Normal University, Jinan 250014, People's Republic of China e-mail: zhaoguoyan@sdnu.edu.cn

G. Zhao · J. Cheng $\cdot$ N. Sun $\cdot$ C. Ma $\cdot$ M. Dai

Shandong Provincial Key Laboratory of Plant Stress Research, Jinan 250014, People's Republic of China content and black deposit characteristics of laboratorycultivated plants before/after co-cultivation of bacteria were investigated by inductively-coupled plasma optical emission spectrometry (ICP-OES), a scanning electron microscope equipped with an energy energy-dispersive $\mathrm{X}$-ray spectroscopye (SEM-EDX), and X-ray fluorescence (XRF). The chemical structures of the biogenic $\mathrm{Mn}$ minerals were characterized via spectra of X-ray diffraction (XRD), energy-dispersive X-ray spectroscopy (EDX), and selected area electron diffraction (SAED). Proteomic analyses, coupled with the enzymic assays were performed to identify the enzymes involved in the Mn oxidation.

Results We observed black deposits containing Mn oxides in the belowground and aboveground tissues of S. salsa. Three Mn-tolerant bacterial strains were isolated from the plants, and two of them possessed Mn(II) oxidation capacities, which were identified as Pantoea eucrina SS01 and Pseudomonas composti SS02. Cocultivation of the two isolates with $S$. salsa showed promoted plant growth and facilitated the formation of black precipitations on roots. Further results showed the different chemical compositions and cellular localizations of biogenic Mn oxides from the two strains. Hydrogen peroxide-detoxifying enzymes were involved in Mn oxidation, most likely mitigating oxidative stresses. Conclusions We suggest a role of endophytic bacteria in Mn uptake and accumulation in the wetland plant S. salsa; our study thereby contributes to a better understanding of the plant-endophyte symbiosis in biogeochemical Mn cycling and wetland soil phytoremediation. 
Keywords Phytoremediation $\cdot$ Manganese $\cdot$ Microbial community $\cdot$ Mn-oxidizing bacteria $\cdot$ Oxidative stresses

$\begin{array}{ll}\text { Abbreviations } \\ \text { ABTS } & \begin{array}{l}2,2 \text {-azinobis-(3-ethylbenzothiazoline-6- } \\ \text { sulphonate) }\end{array} \\ \text { DPI } & \begin{array}{l}\text { diphenyleneiodonium } \\ \text { diethylenetriaminepentaacetic acid }\end{array} \\ \text { DTPA } & \text { inductively coupled plasma optical emission } \\ \text { ICP- } & \text { spectrometry } \\ \text { OES } & \text { leucoberbelin blue } \\ \text { LBB } & \text { 2-methyl-6-(4-methoxyphenyl)-3,7- } \\ \text { MCLA } & \text { dihydroimidazo[1,2-a]pyrazin-3-one } \\ \text { MIC } & \text { minimum inhibitory concentration } \\ \text { MS/MS } & \text { tandem Mass Spectrometry } \\ \text { SAED } & \text { selected area electron diffraction } \\ \text { SEM- } & \text { scanning electron microscope equipped with } \\ \text { EDX } & \text { an energy dispersive } \\ & \text { X-ray spectroscopy } \\ \text { SOD } & \text { superoxide dismutase } \\ \text { TEM } & \text { transmission electron microscopy } \\ \text { XRD } & \text { X-ray diffraction } \\ \text { XRF } & \text { X-ray fluorescence }\end{array}$

\section{Introduction}

Wetlands are often considered as sinks for metal contaminants. For example, the Mn content of coastal marshes in the Yellow River of China ranges from 305.87 to $711.39 \mathrm{mg} / \mathrm{kg}$ (Sun et al. 2013), while the critical toxicity level of $\mathrm{Mn}$ in plants ranges from 200 to $3500 \mathrm{mg} / \mathrm{kg}$ (Krämer 2010). Excessive Mn might compete with other cationic metals in terms of metabolism and transport, resulting in nutrient deficiencies of plants (Fernando and Lynch 2015). Based on numerous previous studies, Suaeda salsa Pall. is a cash crop halophyte and a promising model organism; it grows in the littoral zone of the Yellow River Delta (Song and Wang 2015; Liu et al. 2018; Guo et al. 2015; Guo et al. 2018; Sui et al. 2017; Wang et al. 2015; Zhou et al. 2016). The species accumulates manganese $(\mathrm{Mn})$, copper $(\mathrm{Cu})$, chromium $(\mathrm{Cr})$, lead $(\mathrm{Pb})$, and arsenic (As) and can therefore be used to remove heavy metals from contaminated wetland sediments (Wu et al. 2012; Li et al. 2012). However, the underlying mechanisms of such pollution removal are still unclear. A striking feature of wetland plants is the presence of plaque on their surface, which is composed of iron and Mn oxides and acts as a source and sink of nutrients and pollutions (Sundby et al. 1998; Khan et al. 2016).

One factor that can affect the metal uptake of wetland plants is the presence of microbial symbionts (Weis and Weis 2004). A study on the submerged plant species Egeria densa has revealed that epiphytic bacteria, i.e., Acidovorax, Comamonas, Pseudomonas, and Rhizobi$u m$, have Mn-oxidizing activities, enabling them to form Mn biofilms on their surfaces (Tsuji et al. 2017). This finding provides new insights into the role of bacteria in the mobilization of Mn (II) in plants. Compared to epiphytic organisms, endophytic organisms form more specific associations with plant tissues (Wani et al. 2015). Recently, several endophytic bacteria with a high Mn tolerance have been discovered, with potential applications in the phytoremediation of Mn-polluted soils (Zhang et al. 2015a, 2015b; Yamaji et al. 2016). However, studies on the underlying mechanisms are scarce.

The oxidation of Mn via non-endophytic bacteria has been studies in the last decade (e.g., Tebo et al. 2005), and different pathways have been proposed. Direct $\mathrm{Mn}$ (II) oxidation is catalyzed by multi-copper oxidases (MCOs) (Su et al. 2013; Butterfield et al. 2013; Geszvain et al. 2013), whereas indirect oxidation occurs via the formation of reactive oxygen species (ROS) (Learman et al. 2011; Hansel et al. 2012). The biogenic Mn oxides formed by the different aquatic strains are also diverse. The largest part of the biogenic Mn oxides is represented by hexagonal birnessite [Mn(IV)] (Webb et al. 2005; Miyata et al. 2006), while Mn(III) minerals, also known as bixbyite-like $\mathrm{Mn}_{2} \mathrm{O}_{3}$, are less common (Zhang et al. 2015c; Hosseinkhani and Emtiazi 2011). In general, biogenic $\mathrm{Mn}$ processes require $\mathrm{O}_{2}$ and therefore occur in the surficial environment (Zhang et al. 2015d; Soldatova et al. 2012; Clement et al. 2009). Under reducing conditions, $\mathrm{Mn}$ (II) is mainly converted to rhodochrosite $\left(\mathrm{MnCO}_{3}\right)$ (Benner et al. 1999).

In this study, we isolated two Mn-oxidizing endophytic bacterial strains from the wetland plant $S$. salsa Pall., with the aim to answer the following questions: 1 ) can these endophytes affect the Mn accumulation of the host plant? 2) Are the mechanisms of Mn oxidation similar for endophytic and non-endophytic bacteria? To study the Mn accumulation in S. salsa, the plant was co-cultivated with the two isolates; Mn content was determined via inductively-coupled plasma optical emission spectrometry (ICP-OES), a scanning electron microscope equipped with an energy-dispersive X-ray 
spectroscope (SEM-EDX) and X-ray fluorescence (XRF). The leucoberbelin blue (LBB) test was performed to detect the formation of Mn oxides. To clearify the chemical and molecular mechanisms of Mn oxidation by the two strains, spectra of X-ray diffraction (XRD), energy-dispersive X-ray spectroscopy (EDX), and selected area electron diffraction (SAED) were employed. Subcellular localization of Mn oxides was observed via transmission electron microscopy (TEM). Proteomic analyses, combined with enzymic assays, were also performed to identify the enzymes involved in Mn oxidation. The overall aim of this study was to provide insights into the co-function of endophytic bacteria and plants in biogeochemical Mn cycling in wetland soils.

\section{Materials and methods}

Measurement of $S$. salsa pall. Mn concentration

Samples of S. salsa Pall. were collected in June 2016 from saline sediment of the Yellow River delta, China (GPS coordinates: N $37^{\circ} 51^{\prime}$, E $118^{\circ} 46^{\prime}$ ). The plants was divided into two groups depending on the prescence or absence of black plaques. Leaves from five plants in each group were mixed and dried at $80{ }^{\circ} \mathrm{C}$ for $72 \mathrm{~h}$. Subsequently, the samples were ground into a fine powder, and filtered through a $0.5-\mathrm{mm}$ filter. About $2.0 \mathrm{~g}$ of sample was acid-digested with a mixture containing $60 \% \mathrm{HNO}_{3}$ and $60 \% \mathrm{HClO}_{4}(1: 5 \mathrm{v} / \mathrm{v})$ and digestion was continued for $2 \mathrm{~h}$. Similarly, the samples of roots and shoots were obtained. The Mn concentrations were analyzed via ICP-OES (IRIS Intrepid II XSP, Thermo Fisher Scientific, MA, USA).

Isolation of endophytic bacteria from $S$. salsa pall

Approximately $5 \mathrm{~g}$ of $S$. salsa Pall. leaves were thoroughly rinsed with water to remove sediment and subsequently washed with $100 \mathrm{ml}$ sterile water. The leaves were surface-sterilized by immersion in $0.1 \%$ Tween 80 for $3 \mathrm{~min}$, followed by $0.1 \% \mathrm{HgCl}_{2}$ for $1 \mathrm{~min}$ and $75 \%$ $(\mathrm{v} / \mathrm{v})$ ethanol for $3 \mathrm{~min}$, before being washed with sterilized $\mathrm{H}_{2} \mathrm{O}$ for at least five times. The washed leaves were grounded in a sterilized mortar and $5 \mathrm{ml}$ sterile water were added, followed by incubation at $30^{\circ} \mathrm{C}$ for $48 \mathrm{~h}$ in Mn-supplemented LB medium containing $10 \mathrm{~g} \mathrm{l}^{-1}$ peptone, $5 \mathrm{~g} \mathrm{l}^{-1}$ yeast extract, $10 \mathrm{~g} \mathrm{l}^{-1} \mathrm{NaCl}$, and $2 \mathrm{mM} \mathrm{MnCl}$. By using the standard dilution plating technique, the enriched culture was subsequently incubated for $7 \mathrm{~d}$ on LB agar supplemented with $5 \mathrm{mM}$ $\mathrm{MnCl}_{2}$. The LB agar contains $10 \mathrm{~g} \mathrm{l}^{-1}$ peptone, $5 \mathrm{~g} \mathrm{l}^{-1}$ yeast extract, $10 \mathrm{~g} \mathrm{l}^{-1} \mathrm{NaCl}$, and $15 \mathrm{~g} \mathrm{l}^{-1}$ agar. To ensure complete sterilization, $100 \mu \mathrm{l}$ of the final wash water were spread on LB agar, and no colonies appeared after incubation at $30^{\circ} \mathrm{C}$ for 1 week.

Determination of the minimum inhibitory concentration (MIC) of $\mathrm{Mn}$

The cultures of each isolate were incubated in LB broth supplemented with different concentrations of $\mathrm{MnCl}_{2}$ $(0,10,20,30,35,40,45,50$, and $60 \mathrm{mM})$ at $30^{\circ} \mathrm{C}$ and shaken at $150 \mathrm{rpm}$ for $72 \mathrm{~h}$. Growth was monitored by optical density at $600 \mathrm{~nm}$ using a spectrophotometer. The lowest Mn concentration that inhibited growth was considered as the MIC.

\section{Mn-oxidizing assay}

Leucoberbeline blue (LBB) staining (Krumbein and Altmann 1973; El Gheriany et al. 2009) was carried out as described by Krumbein and Altmann (1973). Briefly, $300 \mu \mathrm{l}$ of each sample were incubated with $60 \mu \mathrm{l}$ of Leucoberbelin Blue 1 (Sigma, $0.04 \%, w / v$ ) and $900 \mu \mathrm{l}$ of acetic acid $(45 \mathrm{mM})$ for $2 \mathrm{~h}$ at $30{ }^{\circ} \mathrm{C}$. The reaction was monitored based on the optical density at $620 \mathrm{~nm}$ using a spectrophotometer. Standard curves were prepared with $\mathrm{KMnO}_{4}$ and $\mathrm{LBB}$, and the results are expressed as $\mathrm{Mn}(\mathrm{IV})$ oxide equivalents.

To determine the intercellular Mn-oxidizing activity of the strains, cell-free extracts were prepared. The strains were grown to the stationary phase in $\mathrm{K}$ media supplemented with $2 \mathrm{mM} \mathrm{MnCl}_{2}$ at $30^{\circ} \mathrm{C}$ and $150 \mathrm{rpm}$. The $\mathrm{K}$ medium ( $1 \mathrm{~L}$ ) was composed of $2 \mathrm{~g}$ peptone, $0.5 \mathrm{~g}$ yeast extract, $0.56 \mathrm{~g} \mathrm{KCl}, 7.24 \mathrm{~g} \mathrm{MgSO}_{4} \cdot 7 \mathrm{H}_{2} \mathrm{O}$, $0.83 \mathrm{~g} \mathrm{CaCl}_{2}$, and $10 \mathrm{~g} \mathrm{NaCl}$. Cells were harvested by centrifugation for $15 \mathrm{~min}$ at $6000 \mathrm{rpm}$ and $4{ }^{\circ} \mathrm{C}$, washed in $100 \mathrm{ml}$ HEPES buffer (20 mM, pH 7.0), recentrifuged, and resuspended in $15 \mathrm{ml}$ HEPES buffer (20 mM, pH 7.0). The mixture was sonicated for $30 \mathrm{~min}$ at $20 \mathrm{kHz}$. The cell-free extract was obtained via collection of the supernatant after centrifugation $(8000 \mathrm{rpm}$ for $30 \mathrm{~min}$ at $4{ }^{\circ} \mathrm{C}$ ). To determine extracellular activity, the strain was grown in $\mathrm{K}$ media at $30{ }^{\circ} \mathrm{C}$ for $10 \mathrm{~d}$, and the supernatant was collected and precipitated by $70 \%$ saturation of ammonium sulfate. The protein precipitates 
were dissolved in HEPES buffer ( $\mathrm{pH} 7.0)$ and dialyzed against the same buffer. The LBB assays were carried out as described above. To test the effects of the components on Mn-oxidizing activity, fresh stocks of various coenzymes, metal ions, and inhibitors were added to the assay mixture.

Identification of Mn-oxidizing bacteria by $16 \mathrm{~S}$ rRNA sequencing

The Mn-oxidizing isolates were grown in LB medium supplemented with $2 \mathrm{mM} \mathrm{MnCl}$ for $24-72 \mathrm{~h}$ at $30{ }^{\circ} \mathrm{C}$ while shaking at $160 \mathrm{rpm}$. Genomic DNA from each isolate was extracted using a DNA isolation kit (BioTeke, Beijing, China) according to the manufacturer's protocol. The 16S rRNA gene sequence of the strains was amplified using Taq DNA polymerase and the primer pair 27F (5'-AGAGTTTGATCCTG GCTCAG-3') and 1492R (5'-TACGGCTACCTTGT TACGACTT-3'). The reaction products were purified with a kit (BioTeke, Beijing, China) and sequenced by BioSune (Shanghai, China). The 16S rRNA sequences were aligned with the BLAST algorithm (Altschul et al. 1990) and the EzTaxon-e service (Kim et al. 2012) and submitted to GenBank. Multiple sequence alignments were analyzed using CLUSTAL_X 2.0 (Larkin et al. 2007). The phylogenetic trees were constructed by the neighbourjoining method (NJ, Saitou and Nei 1987) using the MEGA 6 software (Tamura et al. 2013). Evolutionary distances were calculated according to the Kimura two-parameter model (Kimura 1980). Branch support was calculated by bootstrap analysis.

Cultivation of $S$. salsa pall. In the laboratory

Individuals of $S$. salsa Pall. were precultured in Hoagland solution at $\mathrm{pH} 6.0$ at a temperature range of $25-28{ }^{\circ} \mathrm{C}$ for $10 \mathrm{~d}$. The nutrient solution was replaced every $3 \mathrm{~d}$, and the endophytic bacteria were cultured in $100 \mathrm{ml} \mathrm{LB}$ liquid medium for $48 \mathrm{~h}$ at $30{ }^{\circ} \mathrm{C}$ and $150 \mathrm{rpm}$. Cells were collected via centrifugation, and the precipitates were washed three times with distilled water. Subsequently, S. salsa Pall. plants were exposed to $200 \mu \mathrm{M} \mathrm{MnCl}_{2}$ in Hoagland solution. Each endophytic bacterial strain was inoculated with the plants at a final density of $10^{6} \mathrm{CFU} \mathrm{ml}{ }^{-1}$, and the non-inoculated pot was considered as a control.
Analysis of elements on the surface of $S$. salsa pall. Plants

Surface elements of the collected plants were analyzed with a scanning electron microscope equipped with SEM-EDX, according to a previously described method (Michalak et al. 2011). For this, the root or leaf segments were mounted on an aluminum stub with glue and subsequently gold-sputtered at $15 \mathrm{~mA}$ for $60 \mathrm{~s}$. Afterwards, they were monitored via an SU8010 (Hitachi, Japan) equipped with an EDX spectral detector (Model 550i). The accelerating voltage during monitoring was $20 \mathrm{keV}$. In addition, XRF was applied to detect Mn. The black plaques were cut down from the roots with a sterilized knife and ground in a mortar, followed by oven-drying at $60{ }^{\circ} \mathrm{C}$ for $2 \mathrm{~d}$. Elemental intensities were determined in the Shandong Analysis and Test Center (Jinan, China) via XRF spectrometry (ZSX Primus II, Japan).

XRD analysis of biogenic Mn formed by endophytic bacteria

Strains were grown at $30^{\circ} \mathrm{C}$ for $10-12 \mathrm{~d}$ in $\mathrm{K}$ medium supplemented with $2 \mathrm{mM} \mathrm{MnCl}_{2}$. Cell-free or extracellular extracts were collected and incubated with $0.1 \mathrm{M}$ $\mathrm{MnCl}_{2}$ at $37^{\circ} \mathrm{C}$ for $24 \mathrm{~d}$. For XRD, the precipitates of the incubation were centrifuged at $3000 \times \mathrm{g}$ for $10 \mathrm{~min}$ and subsequently air-dried to obtain $100 \mathrm{mg}$ of powder. The samples were analyzed a Bruker D8-Advance Xray diffractometer (Bruker AXS, Germany) and scanned across the range of $2 \theta$ from $10^{\circ}$ to $85^{\circ}$. The analysis was conducted with $\mathrm{Cu} \mathrm{K} \alpha(\lambda=0.15418 \mathrm{~nm})$ at $40 \mathrm{~mA}$ and $40 \mathrm{kV}$, with a step size of $0.02^{\circ}$ and a scan speed of $10^{\circ} \%$ min. Patterns were analyzed using the JADE 6 (Materials Data, Inc., USA) software and identified according to the International Center for Diffraction Data (ICDD) PDF-2 database (http://www.icdd.com/).

TEM analysis of Mn oxides formed by endophytic bacteria

The bacterial strains were incubated at $30{ }^{\circ} \mathrm{C}$ for $7 \mathrm{~d}$ in liquid $\mathrm{K}$ medium supplemented with $\mathrm{MnCl}_{2}(2 \mathrm{mM})$. For electron microscopy studies of the microspherical traits of the biogenic deposits formed by the strains, cellmineral pellets were collected by centrifugation at $4000 \times \mathrm{g}$ for $15 \mathrm{~min}$ and fixed with $3.0 \%$ glutaraldehyde, followed by washing with $0.1 \mathrm{M}$ phosphate-buffered 
saline (PBS) buffer for three times, staining with $1.0 \%$ $\mathrm{OsO}_{4}$ for $1 \mathrm{~h}$, and washing with PBS buffer for another three times. Four dehydration steps with 30, 50, 70, and $90 \%$ ethanol and absolute dehydration with propylene oxide were carried out prior to embedding with araldite resin (2:1, 1:2, and 100\% propylene oxide: araldite). The samples were cured at $60{ }^{\circ} \mathrm{C}$ before slicing to a 70-nm thickness and staining with $3.0 \%$ uranyl acetate and lead citrate. The ultra-microtome sample was then investigated via a JEM-1200EX microscope. The EDX and SAED were carried out to obtain the elemental and structural information. Samples were coated with amorphous carbon and analyzed using a JEOL 2100F microscope (JEOL, Tokyo, Japan) at $200 \mathrm{kV}$, equipped with an Oxford X-Max 80 T EDX system (Oxford Instruments, Oxford, UK).

\section{Antioxidant activity assay towards ABTS}

The antioxidant activity assays were determined at $30{ }^{\circ} \mathrm{C}$ using ABTS, [2,2-azinobis-(3-ethylbenzothiazoline-6-sulphonate), Sigma, USA] as substrate according to the previously described method (Bohu et al. 2015). The oxidation rate of the substrate was detected by determining absorbance at $420 \mathrm{~nm}$ using a Purkinje TU-1810 UV-VIS spectrophotometer (Beijing Purkinje General Instrument, Beijing, China).

Protein purification and proteomic MS/MS analysis

Strains were grown in $\mathrm{K}$ medium at $30^{\circ} \mathrm{C}$ and $150 \mathrm{rpm}$ for $7 \mathrm{~d}$. The crude proteins of $P$. composti SS02 were prepared via collecting the supernatant of the culture, while the crude protein of $P$. eucrina $\mathrm{SS} 01$ was obtained by collection of the supernatant from centrifugation (8000 rpm for $30 \mathrm{~min}$ at $4{ }^{\circ} \mathrm{C}$ ) after the cells were sonicated. The proteins in the supernatant were precipitated by adding ammonium sulfate powder at a final concentration of $70 \%$. The precipitates were collected by centrifugation ( $8000 \mathrm{rpm}, 15 \mathrm{~min}$ ) and dissolved in $50 \mathrm{mM}$ Tris- $\mathrm{HCl}$ buffer ( $\mathrm{pH}$ 7.0), followed by being placed in a DEAE-Sepharose Fast Flow chromatography column pre-equilibrated with the same buffer. The column was then eluted with a linear gradient of 0 to 1.0 $\mathrm{M} \mathrm{NaCl}$, and the $\mathrm{Mn}$ (II) oxidation activities of the fractions were determined by using the LBB method as described previously. The active fraction was collected for the analysis of $10 \%$ SDS-PAGE. The bands of interest were excised from the gel, digested with trypsin, and sent to Biosune (Shanghai, China) for peptide sequencing, using the UltrafleXtreme MALDI TOF/TOF instrument (Bruker Daltonics, Bremen, Germany).

\section{Detection of uperoxide production}

Superoxide was detected with the chemiluminescent probe MCLA (2-methyl-6-(4-methoxyphenyl)-3,7dihydroimidazo[1,2-a]pyrazin-3-one), following the protocol established by Learman et al. (2011). Briefly, basic luminescence was calculated by preparing a mixture of xanthine $(50 \mu \mathrm{M})$ and diethylenetriaminepentaacetic acid (DTPA, $100 \mu \mathrm{M}$ ) and $280 \mu \mathrm{l}$ of the purified active solution parts collected after DEAE-Sepharose chromatography. A blank measurement was performed by adding SOD (50 kU/l) to the above mixture to remove superoxide. The superoxide production of the sample was monitored by adding $12.5 \mu \mathrm{M}$ of MCLA to the basic mixture and reaching the steady stage after $5 \mathrm{~min}$.

\section{Results}

Mn accumulation in $S$. salsa pall

In June, we collected plants of $S$. salsa Pall. from the coastal area of the Yellow River, China. In one group (G1), a layer of black plaques was observed on the surface of roots and stems (Fig. 1a), while the other group (G2) showed no such layer (Fig. 1a). Dissection of plants from G1 revealed that black precipitates also appeared in the inner tissues, known as pith (Fig. S1A). In LBB staining, roots from G1 showed a blue color, while the roots from G2 were colorless (Fig. 1b). This suggests that the black plaques from G1 contained Mn oxides (Krumbein and Altmann 1973; El Gheriany et al. 2009). Based on the results of the SEM-EDX analysis, the plaque contained $\mathrm{Mn}, \mathrm{C}, \mathrm{O}, \mathrm{Cl}$, and $\mathrm{K}$ (Fig. 1d, e). Similarly, analysis of the black precipitates in the pith confirmed the presence of Mn, Fe, C, and O (Fig. S1C, D). Although there was no visible black precipitates on the leaves of $S$. salsa Pall., the LBB test was positive for the leaves from individual plaque-covering plants, indicating the accumulation of Mn oxides on the surface of leaves. In contrast, the test was negative for non-covered plants (Fig. 1b). These results suggest that Mn oxides are accumulated as dark precipitates on both belowground and aboveground tissues of $S$. salsa Pall. 
a

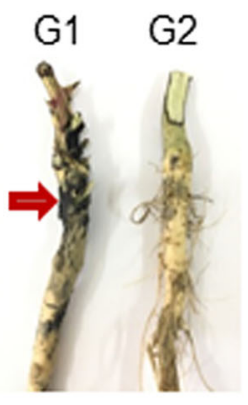

b

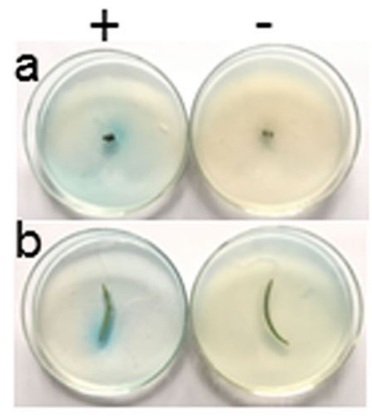

C

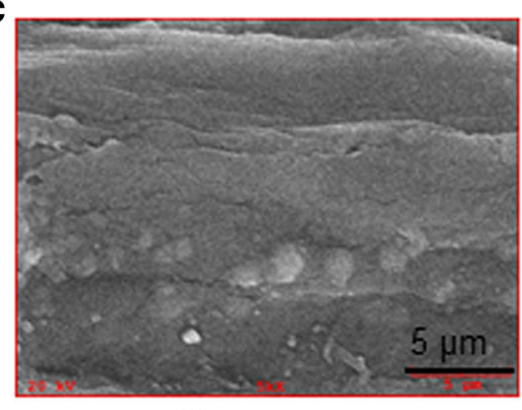

e

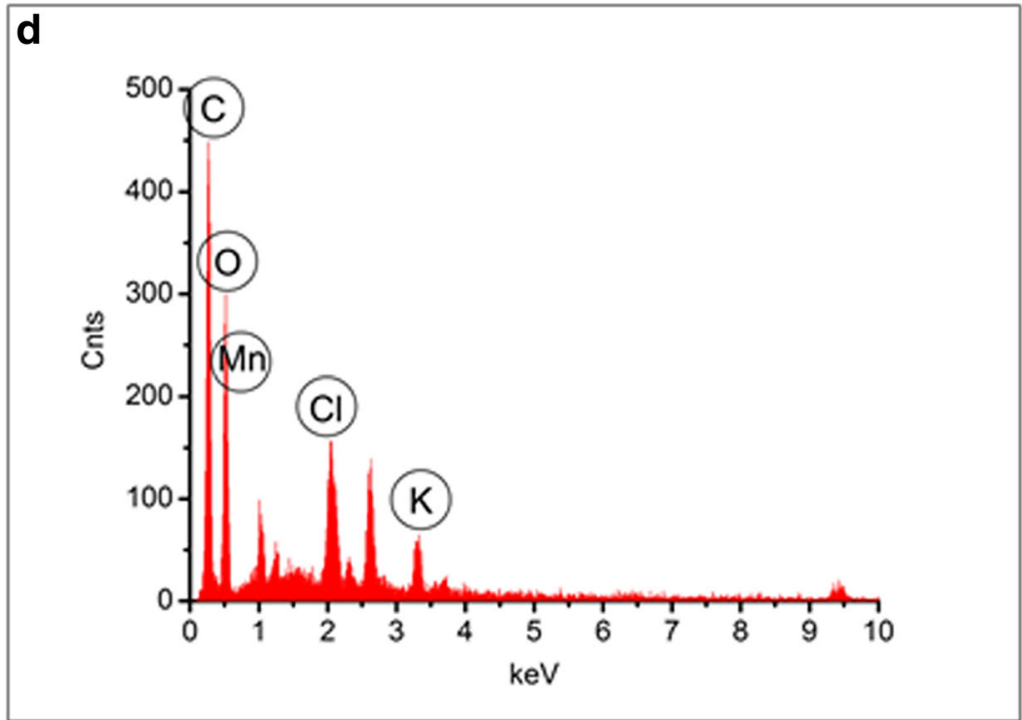

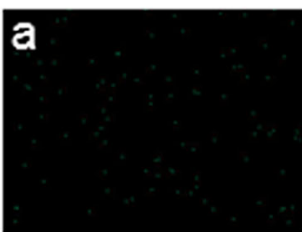
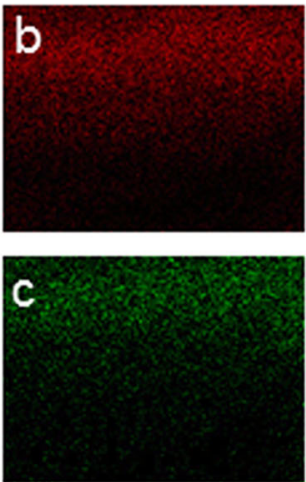

Fig. 1 Precipitation of Mn-containing plaques on the surface of Suaeda salsa Pall. A, Field collected S. salsa Pall. with (G1) and without (G2) visible black plaques on the surface of the root. A segment of root with black precipitations (indicated by red arrow) was mounted onto an aluminum stub for SEM-EDX analysis. B, LBB staining of the root (a) and leaf (b) from S. salsa Pall. with (+)

We also measured the Mn concentrations in different tissues of S. salsa Pall. via ICP-OES. For plants from G1, the Mn concentrations of the root, shoot, and leaves were 14,9 and $10 \mathrm{mg} / \mathrm{kg}$, respectively (Fig. S2). By comparison, plants from G2 contained lower amounts of Mn, namely 9, 4, and $4 \mathrm{mg} / \mathrm{kg}$ for root, shoot, and leaves, respectively (Fig. S2). These results indicate that the presence of black precipitates was associated with elevated $\mathrm{Mn}$ concentrations in the tissues of $S$. salsa Pall.

Isolation and identification of Mn-oxidizing endophytic bacteria from $S$. salsa pall

By cultivation in LB medium supplemented with $5 \mathrm{mM}$ $\mathrm{MnCl}_{2}$, a total of three isolates were cultured from S. salsa Pall. plants coated with black plaques (G1). and without (-) visible black plaques. C, SEM view of the root with a location indicated by the arrow in Fig. A. D, Elemental analysis by EDX of the surface of the analyzed region (as showed in Fig. C) showing the appearance of several metals, including Mn. E. Individual EDX elemental distribution maps for Mn (a), C (b), and $\mathrm{O}$ (c)

The three strains were tolerant to $\mathrm{MnCl}_{2}$ at a range from 10 to $45 \mathrm{mM}$ (Table 1). Two of these isolates, strain SS01 and SS02, had Mn(II)-oxidizing activity as indicated by LBB staining. Strain SS01 exhibited an activity of $585 \mu \mathrm{M}$ of the equivalent $\mathrm{MnO}_{2}$, whereas strain SS02 had a relatively lower activity at $169 \mu \mathrm{M}$ (Table 1). Sequences of the amplified 16S rRNA of the two strains showed that they belonged to the genera Pantoea and Pseudomonas. Strain 1 showed $100 \%$ similarity of the 16S rRNA sequence with Pantoea eucrina PSNIH1 (GenBank no. CP009880) and thus was identified as Pantoea eucrina SS01. Strain 2 was ascribed to Pseudomonas composti SS02 as the 16S rRNA sequence showed 99\% similarity with Pseudomonas composti CCUG 59231 (GenBank no. FOWP01000025). The third endophytic isolate, Enterobacter sp. SS03, 
Table 1 Identification, description and Mn-oxidizing ability of endophytic bacteria isolated from Suaeda salsa Pall

\begin{tabular}{|c|c|c|c|c|c|c|c|}
\hline Isolate* & $\begin{array}{l}\text { Accession } \\
\text { no. }\end{array}$ & $\begin{array}{l}\text { Gene annotation } \\
\text { of the top-hit strain } \\
\text { (accession no.) }\end{array}$ & $\begin{array}{l}\text { Identity } \\
(\%)\end{array}$ & $\begin{array}{l}\mathrm{MIC} \\
(\mathrm{mmol} / \mathrm{l})\end{array}$ & $\begin{array}{l}\mathrm{Mn}(\mathrm{II}) \text {-oxidizing } \\
\text { activity (MOA) } \\
\text { of formed } \mathrm{MnO}_{2} \\
(\mu \mathrm{M})^{\dagger}\end{array}$ & $\begin{array}{l}\text { Intercellular } \\
\text { MOA } \\
\text { activity }\end{array}$ & $\begin{array}{l}\text { Extracellular } \\
\text { MOA } \\
\text { activity }\end{array}$ \\
\hline SS01 & MF086656 & Pantoea eucrina PSNIH1 (CP009880) & 100 & 30 & 586 & + & - \\
\hline $\mathrm{SS} 02$ & MF086658 & $\begin{array}{l}\text { Pseudomonas composti CCUG } 59231 \\
\quad \text { (FOWP01000025) }\end{array}$ & 99 & 10 & 169 & $\mathrm{w}$ & + \\
\hline $\mathrm{SS} 03$ & MF086659 & $\begin{array}{l}\text { Enterobacter aerogenes KCTC } 2190 \\
\quad(\mathrm{CP} 002824)\end{array}$ & 99 & 45 & 0 & - & - \\
\hline
\end{tabular}

*Isolates were selected by cultivation with $5 \mathrm{mM} \mathrm{Mn(II)} \mathrm{supplemented} \mathrm{in} \mathrm{LB} \mathrm{medium}$

\# By alignment using the BLAST algorithm (Altschul et al. 1990) and the EzTaxon-e service (Kim et al. 2012). Uncultured bacteria were manually removed

${ }^{\dagger}$ Strains were grown in $\mathrm{K}$ media supplemented with $2 \mathrm{mM} \mathrm{MnCl}_{2}$ at $30^{\circ} \mathrm{C}$ for $7 \mathrm{~d}$

+ positive, - negative, w weak

presented a high tolerance to $\mathrm{MnCl}_{2}$ at $45 \mathrm{mM}$, but its LBB test was negative (Table 1, Fig. S3).

Phylogenetic analysis of the reported Mn-oxidizing strains illustrated that the two isolates were both clustered within the Gammaproteobacteria phylum of the class Proteobacteria (Fig. 2), which includes several model Mn-oxidizing bacteria that have been isolated from aquatic areas, such as Roseobacter sp. AzwK-3b (Learman et al. 2011), Aurantimonas manganoxydans SI85-9A1 (Anderson et al. 2009) and Leptothrix discophora SS-1 (Adams and Ghiorse 1986). Moreover, the two isolates were clustered together with a short phylogenetic distance and were separated from those above-mentioned marine bacteria.

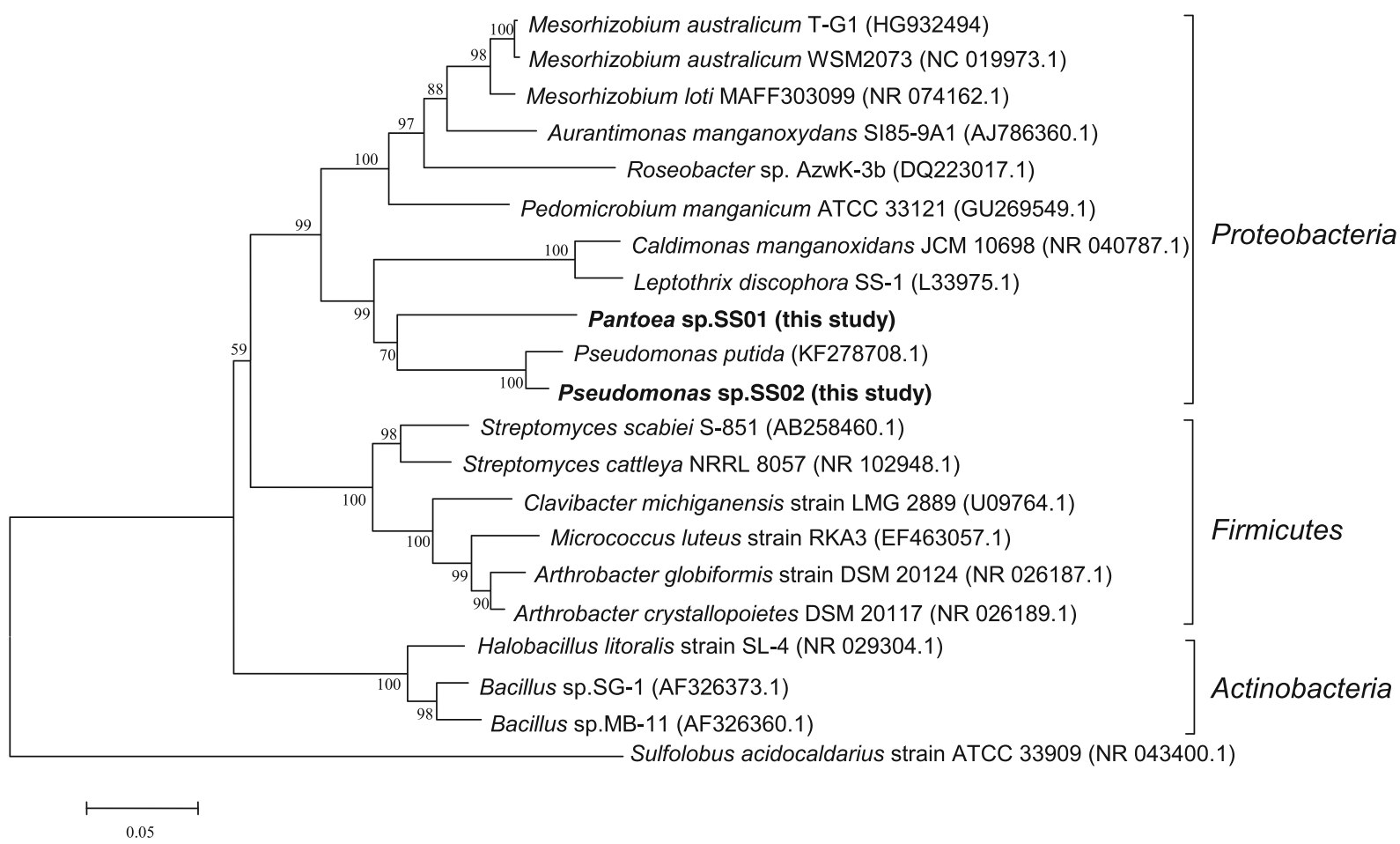

Fig. 2 The neighbour-joining (NJ) tree based on 16S rRNA gene sequences of $\mathrm{Mn}(\mathrm{II})$ oxidizing bacteria (MOB) isolated in this work (indicated by boldface type) and previously reported MOB strains. The 16S rRNA sequence of Sulfolobus acidocaldarius strain ATCC 33909 was used as an outgroup. Bootstrap values are expressed as percentages of 1000 replications, and only bootstrap values above $50 \%$ are shown. GenBank accession numbers are given in parentheses. Bar, 0.05 substitutions per nucleotide 
a

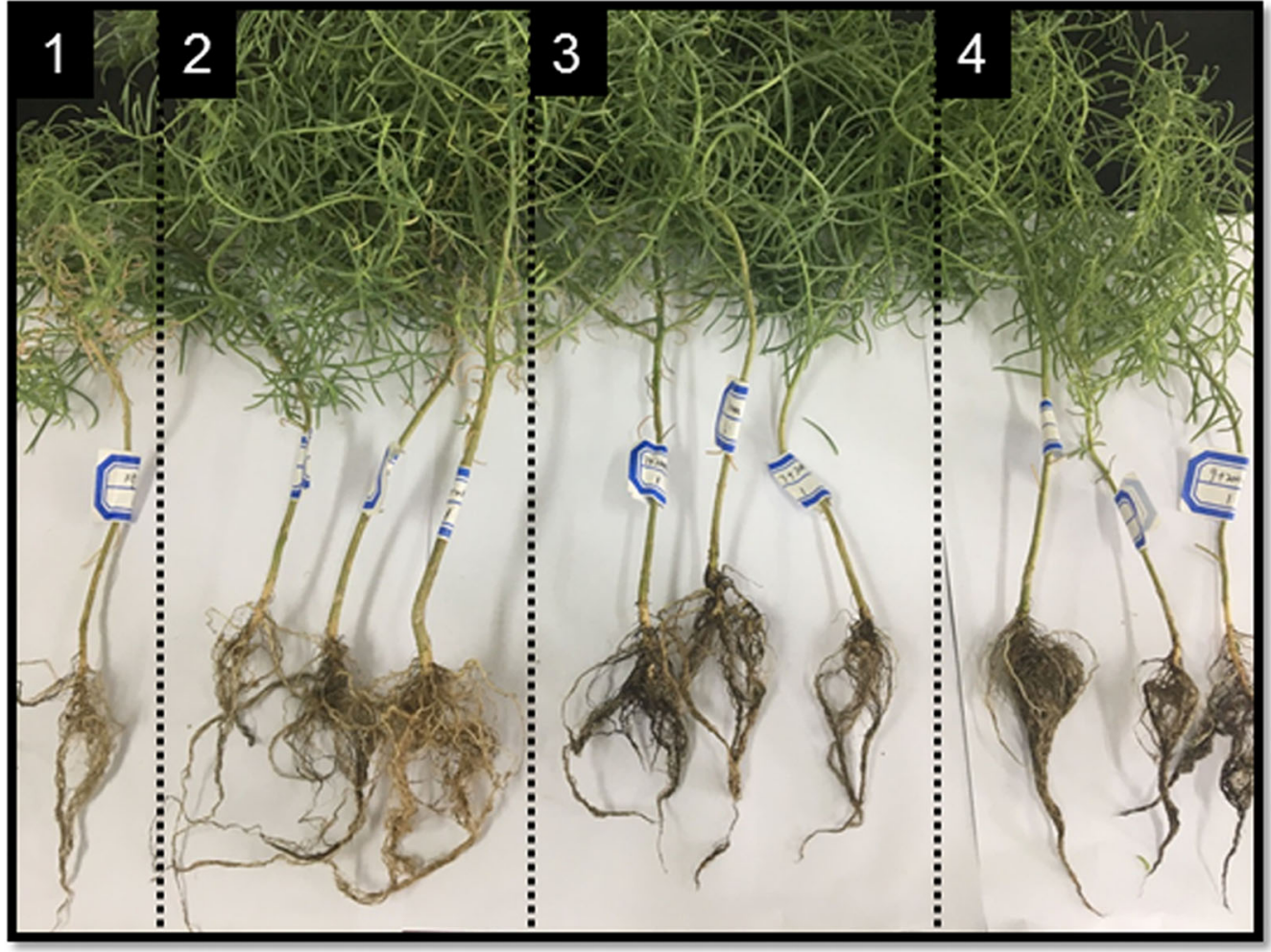

b

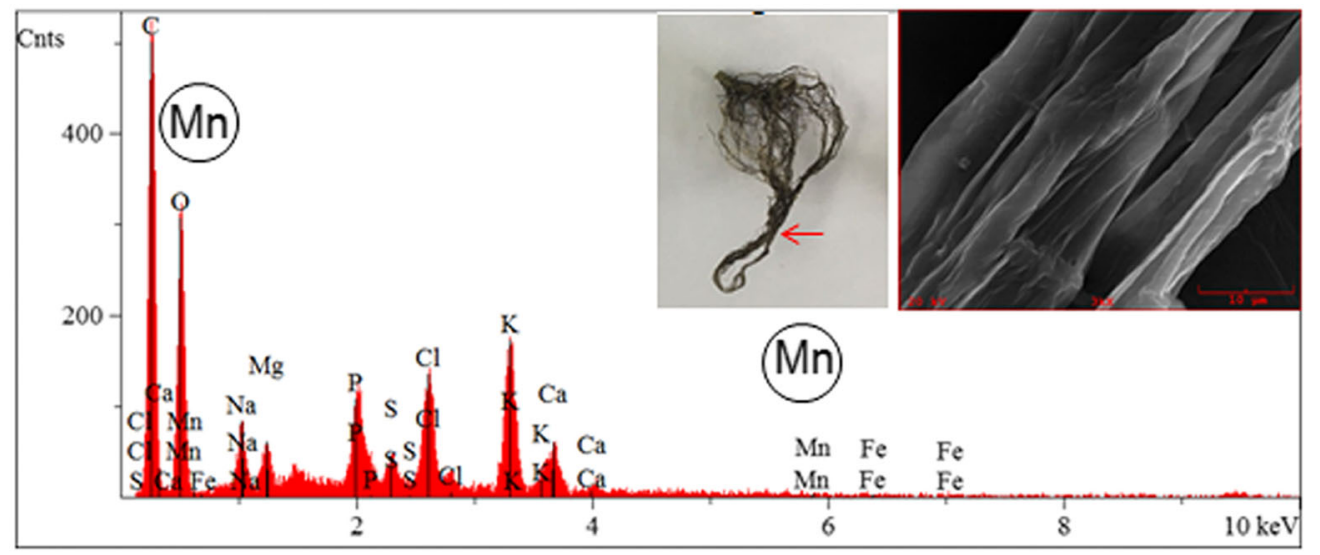

C

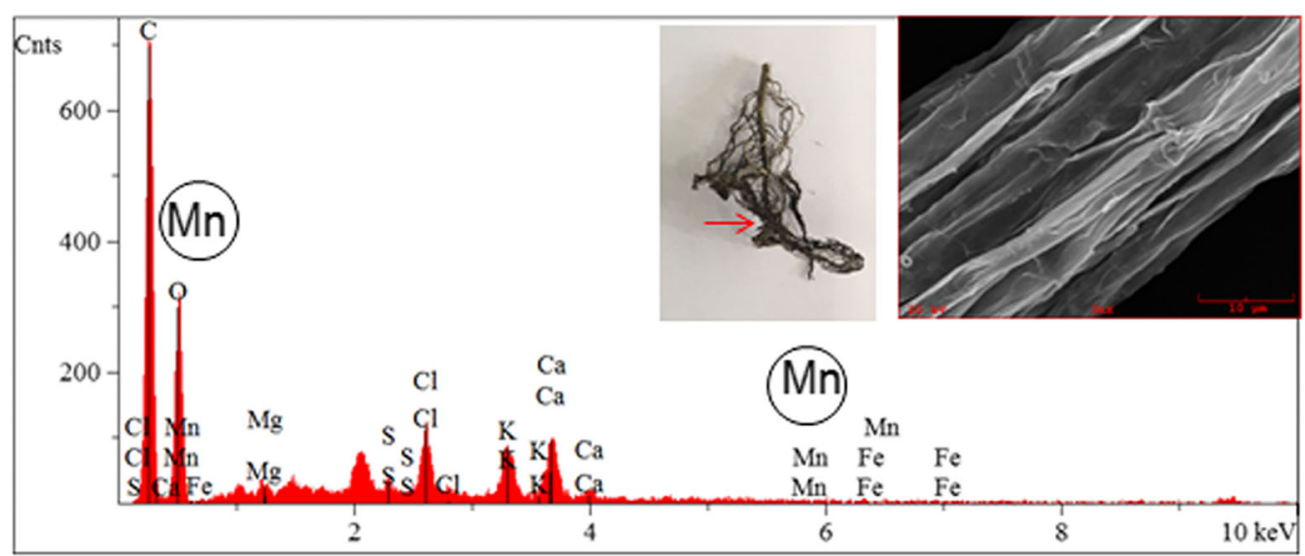


Fig. 3 Mn precipitation on the root of laboratory-cultivated $S$. salsa Pall. A, Photographs of laboratory-cultivated S. salsa Pall. plants. 1, plant cultured by Hoagland solution for $30 \mathrm{~d}$; 2, plants exposed to $200 \mu \mathrm{M} \mathrm{MnCl}_{2}$ in Hoagland solution for $30 \mathrm{~d}$; 3, plants co-cultured with P. eucrina SS01 and Hoagland solution with $200 \mu \mathrm{M} \mathrm{MnCl}_{2}$ for $30 \mathrm{~d}$; 4, plants co-cultured with $P$. composti SS02 and Hoagland solution with $200 \mathrm{mM} \mathrm{MnCl}_{2}$ for $30 \mathrm{~d}$. B, Elemental analysis by EDX of the surface of root from plant co-cultured with P. eucrina SS01 (as indicated by the arrow in inset). C. Elemental analysis by EDX of the surface of root from plant co-cultured with P. composti $\mathrm{SS} 02$ (as indicated by the arrow in inset)

Mn precipitation on laboratory-cultivated plants mediated by the bacteria

Black precipitates are rarely reported in plants cultivated under laboratory conditions (Tsuji et al. 2017). In this work, we observed that when $S$. salsa Pall. plants were cultured with $200 \mu \mathrm{M} \mathrm{MnCl} \mathrm{M}_{2}$ for $30 \mathrm{~d}$, a few roots turned black, whereas most of the plants showed no apparent symptoms (Fig. 3). However, when plants were co-cultured with Mn-oxidizing endophytic bacteria and $200 \mu \mathrm{M} \mathrm{MnCl}_{2}$ for $30 \mathrm{~d}$, black precipitates were clearly observed on the surface of all roots (Fig. 3). The LBB staining of black precipitates was positive, suggesting the accumulation of Mn oxides. Further, SEMEDX analysis showed that the precipitates were composed of $\mathrm{Mn}$, in addition to $\mathrm{C}, \mathrm{O}, \mathrm{K}, \mathrm{Cl}, \mathrm{P}$ and other elements (Fig. 3). The XRF also showed the presence of $\mathrm{Mn}$ in the black precipitates of the plants cultivited with strains SS01 and SS02, whereas no Mn signal could be detected for untreated plant roots (Fig. S4). These results indicate the involvement of endophytic Mn-oxidizing bacteria in the accumulation of Mn oxides in S. salsa Pall.plants.

Characterization of the chemical composition of biogenic Mn oxides

For P. eucrina SS01, TEM revealed the presence of 50$\mathrm{nm}$-thick and rounded deposits of electron-dense material in the membranes of the cells (Figs. 4a, S5A). According to the results of the EDX analysis, the deposits were mainly composed of Mn, C, and O (Fig. $4 \mathrm{Ca}$ ). However, electron diffraction of deposits formed by $P$. eucrina $\mathrm{SS} 01$ showed no visible diffraction spots (Fig. 4Cb, inset), probably because of the effects of cells or cell membranes mixed with the Mn minerals. As depicted in Fig. 4e, the XRD patterns of the Mn aggregates from $P$. eucrina SS01 exhibited five distinct peaks at angles of $23.8^{\circ}, 30.7^{\circ}, 40.7^{\circ}, 44.5^{\circ}$, and $50.5^{\circ}$ corresponding to $\mathrm{MnCO}_{3}$ (JCPDS 44-1472) (Fig. 4Ea), as well as two peaks at $27.7^{\circ}$, and $37.1^{\circ}$ (Fig. 4Eb), typical for $\mathrm{MnO}_{2}$ (JCPDS 44-0142).

For $P$. composti $\mathrm{SS} 02$, the precipitation of nontransparent and irregular deposits was only observed away from the cells (Figs. 4b, S5B), indicating an extracellular reaction. The EDX showed that deposits were also composed of $\mathrm{Mn}$ and $\mathrm{O}$ along with other elements (Fig. $4 \mathrm{Da}$ ). The SAED pattern analysis showed that diffraction spots were arranged as continuous rings (Fig. $4 \mathrm{Db}$, inset), suggesting that the deposits were heteromorphic and crystallographic. The XRD pattern of Mn deposits of $P$. compost $\mathrm{SS} 02$ showed two main peaks at $33.5^{\circ}$ and $55.4^{\circ}$ (Fig. $4 \mathrm{Fb}$ ), representing $\mathrm{Mn}_{2} \mathrm{O}_{3}$ (JCPDS 41-1442). The presence of $\mathrm{MnCO}_{3}$ was also confirmed by five typical peaks at $24.3^{\circ}, 31.2^{\circ}, 37.3^{\circ}, 41.3^{\circ}$, and $51.5^{\circ}$ (Fig. 4Fa, Ga, JCPDS 44-1472). Additionally, the intense peaks at $31.8^{\circ}$ and $45.5^{\circ}$ indicated the presence of $\mathrm{NaCl}$ (Fig. 4Fc, Gc, JCPDS 05-0628).

Molecular mechanisms involved in the Mn(II) oxidation

The different locations and compositions of the minerals from the two strains indicate distinct mechanisms of bacterial $\mathrm{Mn}$ (II) oxidation. To confirm this, we performed LBB analysis to examine the intercellular and extracellular Mn-oxidizing activities in P. eucrina SS01 and P. composti SS02. In $P$. eucrina SS01, Mn-oxidizing activity was detected only in the cell lysate, whereas the activity of P. composti SS02 occurred extracellularly (Table 1). These results were in line with the TEM observations (Fig. 4a, b), suggesting that $\mathrm{Mn}$ (II) oxidation occurred in the different locations of cells of the two strains.

Furthermore, the molecular mechanism of Mn oxidazation was studied. The effect of chemicals on the $\mathrm{Mn}(\mathrm{II})$ oxidation was investigated. For P. eucrina SS01, addition of NADH $(400 \mu \mathrm{M})$ stimulated activity (1.4-fold), while SOD (15 kU) decreased the activity (Table $\mathrm{S} 1$ ). It should be noted that NADH is a substrate of NADH-oxidase and incrases superoxide $\left(\mathrm{O}_{2}{ }^{-}\right)$production (Vinogradov and Grivennikova 2005), whereas SOD serves as a scavenger of reactive oxygen species (ROS) (Learman et al. 2011). These results suggest that the formation of Mn oxides of $P$. eucrina $\mathrm{SS} 01$ might be associated with ROS generation (Learman et al. 2011). Moreover, the addition of the oxidoreductase inhibitor diphenyleneiodonium (DPI) quenched $50 \%$ of the $\mathrm{Mn}$ (II)-oxidizing activity (Fig. 5a). In a previous study, 

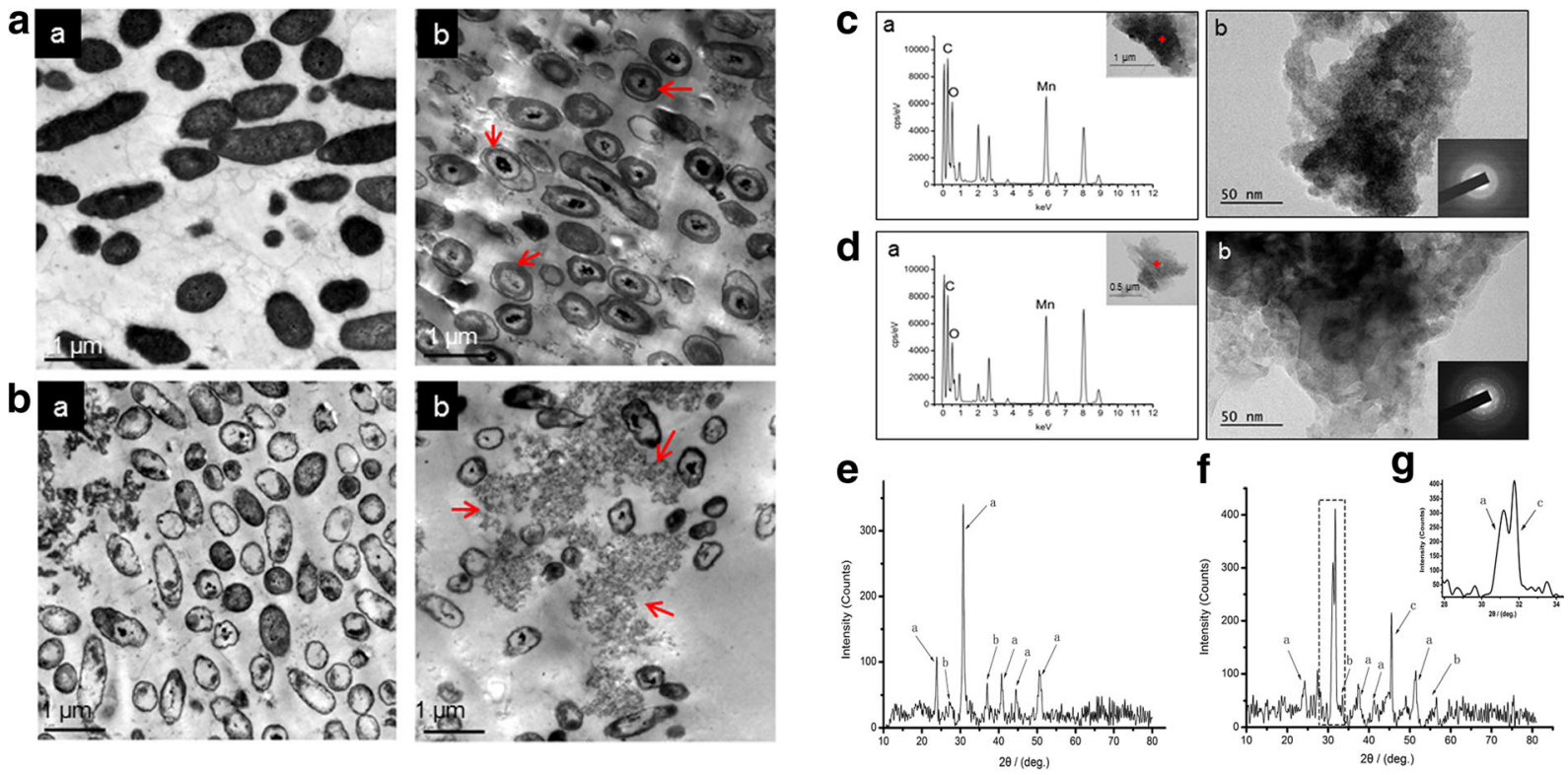

Fig. 4 The subcellular localization and chemical composition of biogenic Mn oxides obtained by the endophytic bacterial strains. A,B, TEM views of the ultrastructures of $P$. eucrina $\mathrm{SS} 01$ (A) and P. composti $\mathrm{SS} 02$ (B) cells with (a) or without (b) incubation of $\mathrm{MnCl}_{2}$. Strains were incubated in $\mathrm{K}$ media supplemented with $2 \mathrm{mM} \mathrm{MnCl}_{2}$ at $30{ }^{\circ} \mathrm{C}$ for $7 \mathrm{~d}$. Arrows indicate the electrondense of Mn deposits. C,D, TEM analysis of the Mn deposits produced by $P$. eucrina $\mathrm{SS} 01$ (C) and $P$. composti SS02 (D) cells.

DPI inhibited peroxidase-mediated superoxide $\left(\mathrm{O}_{2}{ }^{-}\right)$ production (Minibayeva et al. 2001). In our study, we observed the production of NADH-stimulated superoxide in strain SS01. We tried to isolate and purify the proteins responsible for $\mathrm{Mn}$ oxidization in strain SS01, and the active components were tested by LBB staining and collected after DEAE-Sepharose chromatography; however, SDS-PAGE showed that the band of the active parts was weak (Fig. 5d), and was identified as catalase by mass spectrometry (Table 2). Since previous studies showed that the ROS mediates $\mathrm{Mn}$ (II) oxidation via a variety of ROS scavengers (Learman et al. 2011), we assumed that the purified catalase might function as a chemical scavenger in detoxification of the intracellular ROS, and participated in the Mn oxidation indirectly. Previous works have identified the ROS-mediating $\mathrm{Mn}(\mathrm{II})$ oxidation compound as superoxide (Learman et al. 2011, 2013). Thus, we detected superoxide in the collected active component by adding MCLA, a superoxide-specific chemiluminescent probe (Godrant et al. 2009; Learman et al. 2011). The significantly increased

a. Elemental analysis by EDX of the minerals formed by the strains. +, Corresponding selected area for EDX analysis. b. TEM micrograph of a cluster of Mn minerals and corresponding selected area diffraction patterns. E, XRD pattern of $\mathrm{MnCO}_{3}$ (a) and $\mathrm{MnO}_{2}$ (b) produced by $P$. eucrina SS01. F, XRD pattern of $\mathrm{Mn}_{2} \mathrm{O}_{3}$ (a), $\mathrm{MnCO}_{3}$ (b), and $\mathrm{NaCl}$ (c) produced by $P$. composti $\mathrm{SS} 02$. G, an amplification of peaks indicated in the dashed quadrilateral area in Fig. F

chemiluminescence intensity indicated the reaction of MCLA with superoxide $\left(\mathrm{O}_{2}{ }^{-}\right)$(Fig. 5b). These results strongly suggest that superoxide $\left(\mathrm{O}_{2}{ }^{-}\right)$plays an important role in Mn oxidization of strain $\mathrm{SS} 01$.

For $P$. composti $\mathrm{SS} 02$, the addition of $\mathrm{NADH}$ had no significant effect on the Mn-oxidizing rate (Table S1). However, the addition of $10 \mu \mathrm{M}$ coenzyme Q, a chemical that decreases the oxidative stress of cells and increases the expression of antioxidant parameters such as superoxide dismutase and catalase, significantly increased the oxidation rate by 1.3 times (Table $\mathrm{S} 1$ ). In addition, DPI $(100 \mu \mathrm{M})$ reduced $53 \%$ of the $\mathrm{Mn}$ (II)oxidizing activity (Fig. 5a). Thus, the results suggest a correlation between Mn oxidization and ROS in strain SS02, but the mechanism was probably different that for strain SS01. Moreover, $\mathrm{Cu}^{2+}(100 \mu \mathrm{M})$ increased the oxidation rate of the cells by 1.4 times (Fig. 5a; Table S1), and the antioxidant activity of strain SS02 against ABTS was $0.296 \mathrm{OD}^{-1} \mathrm{ml}^{-1}$, whereas the ABTS activity $\left(0.030 \mathrm{OD}^{-1} \mathrm{ml}^{-1}\right)$ of strain SS01 was neglectable (Fig. 5c). Furthermore, the proteins of strain $\mathrm{SS} 02$ were separated by DEAE-Sepharose chromatography, and the active band was identified as catalase-peroxidase by mass 


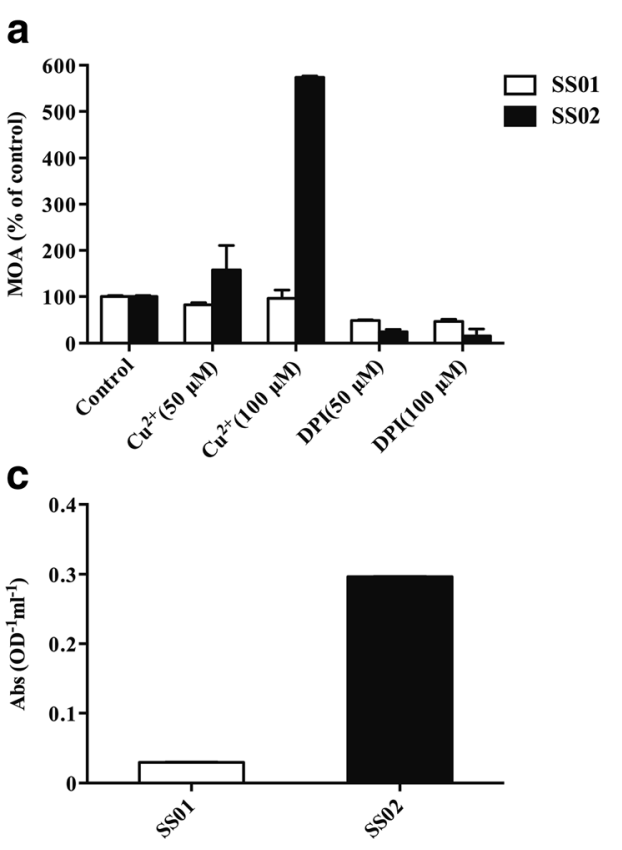

Fig. 5 The enzyme assays and purified proteins. A, The Mn(II)oxidizing activities of $P$. eucrina SS01 (white bars) and $P$. composti $\mathrm{SS} 02$ (black bars) under different chemicals. Experimental data normalized to control, the standard condition with no added chemicals. Concentrations of Mn oxides were determined using LBB (Krumbein and Altmann 1973). B, The superoxide production by $P$. eucrina SS01and $P$. composti SS02. Luminescences was calculated by adding $12.5 \mu \mathrm{M}$ of MCLA to basic mixtures containing $50 \mu \mathrm{M}$ xanthine, $100 \mu \mathrm{M}$ DTPA, and

spectrometry (Table 2), which is consistent with the ABTS and DPI tests. The active protein solutions also showed a 3 -fold increase in the $\mathrm{Mn}$ (II)-oxidizing activity when $\mathrm{Cu}^{2+}(100 \mu \mathrm{M})$ was added (Fig. 5a), further indicating the differential $\mathrm{Mn}$ oxidizing mechanisms between strain SS01 and strain SS02. b
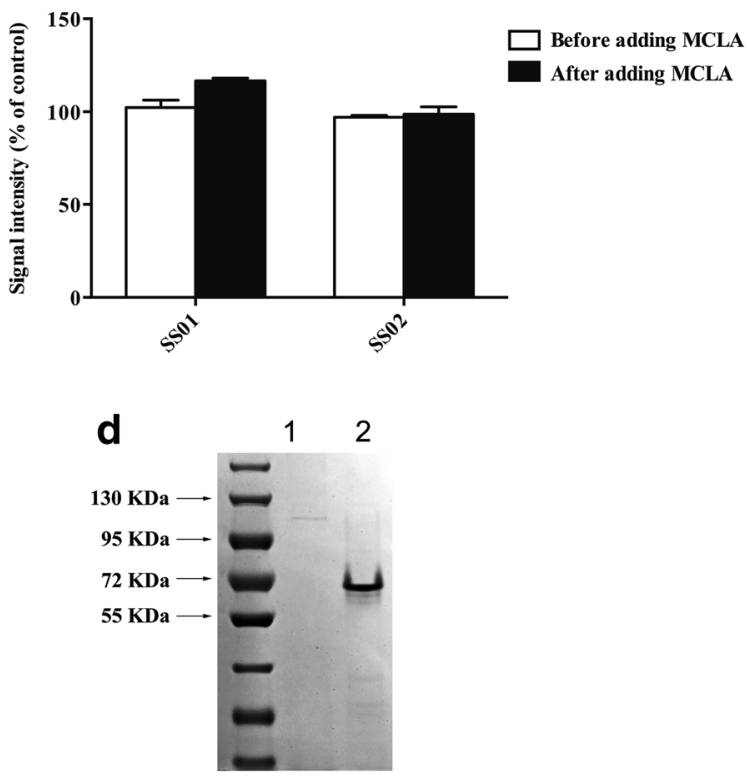

$280 \mu \mathrm{l}$ of the active solutions collected after DEAE-Sepharose. Experimental data normalized to the blank measurement by adding SOD $(50 \mathrm{kU} / \mathrm{l})$ to the basic mixtures to remove superoxide. C, The ABTS activities of $P$. eucrina SS01 and $P$. composti SS02. Activities were determined at $30{ }^{\circ} \mathrm{C}$ using $0.5 \mathrm{mM}$ ABTS as substrate. D, The active protein parts from $P$. eucrina SS01 (1) and $P$. composti SSO2 (2) that were collected after DEAE-Sepharose, and were analyzed by $10 \%$ SDS-PAGE. The activities of the protein solutions were determined by LBB methods

\section{Discussion}

Wetlands can represent sinks for heavy metals and other pollutants, thereby providing important phytoremediation services. The fate of heavy metals within plant tissues is critical in the circulation of

Table 2 MS/MS peptide identification of the protein bands in filtrate active for Mn(II) oxidation

\begin{tabular}{|c|c|c|c|c|}
\hline Isolates & Protein locus ${ }^{\mathrm{a}}$ & Protein description & $\begin{array}{l}\text { Estimated } \\
\mathrm{MW}(\mathrm{kDa})^{\mathrm{b}}\end{array}$ & $\begin{array}{l}\text { Total spectral } \\
\text { counts }\end{array}$ \\
\hline SS01 & A0A1X1DHL6 & Catalase & 55 & 150 \\
\hline SS01 & A0A1X1DJZ7 & ATP-binding protein & 56 & 48 \\
\hline SS01 & A0A1X1DT32 & Two-component system response regulator & 27 & 43 \\
\hline $\mathrm{SS} 02$ & A0A1I5S769 & Catalase-peroxidase & 78 & 43 \\
\hline SS02 & A0A1I5PWF7 & Pyridoxine/pyridoxamine 5 '-phosphate oxidase & 24 & 42 \\
\hline $\mathrm{SS} 02$ & A0A1I5QW64 & Putative protein & 7 & 39 \\
\hline
\end{tabular}

\footnotetext{
${ }^{\mathrm{a}}$ GenBank designation

${ }^{\mathrm{b}}$ Molecular weights were estimated based on amino acid sequences

${ }^{c}$ For counts, peptide probability was set at $>95 \%$, and protein probability was set at $>99.9 \%$ using Scaffold, minimum of 2 peptides
} 
elements within wetlands (Weis and Weis 2004). Manganese is an essential constituent of PSII during oxygenic photosynthesis, but at high concentrations, it restricts plant growth (Fernando and Lynch 2015). The oxidation of $\mathrm{Mn}$ is a profound way to reduce the $\mathrm{Mn}$ toxicity of this heavy metal, and the oxidizing process in situ is considered to involve fungi and bacteria (Spiro et al. 2009). However, the interactions between plants and Mn-oxidizing bacteria are still unclear. Recent studies have focused on the physiological factors of plants in Mn uptake, transport, and release (Fernando and Lynch 2015), whereas the effectiveness of microbial symbionts in this process has not been clarified so far. In this study, we isolated three Mn-tolerant endophytic strains from the leaves of $S$. salsa Pall. by a culture-based approach. Among these isolates, two Proteobacteria strains, Pantoea eucrina SS01 and Pseudomonas composti $\mathrm{SS} 02$, were found to have Mn-oxidizing abilities. Previous studies have shown that Pseudomonas strains could be divided into non-Mn-oxidizing and $\mathrm{Mn}$ oxidizing families (Jung and Schweisfurth 1979; Geszvain et al. 2013). The strain P. composti SS02, which has also been isolated from salt marshes in heavy metal-contaminated areas (Andrades-Moreno et al. 2014), is a new member of Mn-oxidizing Pseudomonas. In comparison, P. eucrina $\mathrm{SS} 01$, isolated in this work is a novel Mn-oxidizing bacterial strain, and the role of the genus Pantoea in Mn oxidation has not been studied.

So far, most $\mathrm{Mn}$ (II)-oxidizing bacteria have been isolated from aquatic environments; only a few works were conducted in terrestrial environments (Zhang et al. 2015c). Several Mn-oxidizing strains of epiphytic bacteria have been found on the surface of field-collected E. densa plants, affecting Mn accumulation (Tsuji et al. 2017). However, for none of the endophytic bacterial species, Mn oxidization has been observed. The discovery of two Mn-oxidizing endophytic bacterial strains from S. salsa Pall. significantly contributes to our knowledge of the habitat and diversity of $\mathrm{Mn}$ oxidizing bacterial species.

Although the presence of plaques composed of iron and $\mathrm{Mn}$ oxides have been enigmatically reported on the surface of wetland plants (Mendelssohn and Postek 1982; Vale et al. 1990), yet few studies have clarified the morphology and composition of these metal-rich rhizoconcretions (Sundby et al. 1998; Weis and Weis 2004) and the mechanism underlying their formation is unclear. In this study, we observed black precipitations from the wetland plant $S$. salsa Pall. collected from wild habitat, as well as from the laboratory-cultivated plants. We also showed that the black precipitations appeared not only on the surface of the root but also in the pith of the plants. LBB staining and SEM-EDX analysis further indicated that $\mathrm{Mn}$ oxides present in the precipitations. A previous study has suggested that the production of biogenic Mn oxides in biofilms on the epidermis of an Mn hyperaccumulator plant, Egeria densa, can elevate Mn levels inside the plants (Tsuji et al. 2017). In this study, however, the concentrations of $\mathrm{Mn}$ in the leaves, stems, and roots of $S$. salsa Pall. with deposition of biogenic $\mathrm{Mn}$ on the surface were all below $20 \mathrm{mg} / \mathrm{kg}$, higher compared with the Mn concentrations of tissues from $S$. salsa plants without Mn deposits, but far below the level of $10,000 \mathrm{mg} / \mathrm{kg}$ found in $\mathrm{Mn}$ hyperaccumulating plants (Fernando et al. 2010). Although the production of Mn might be influenced by the growth state, the season, and other environmental parameters, we can argue here that $S$. salsa Pall. is not an $\mathrm{Mn}$ hyperaccumulator. In Mn hyperaccumulators, Mn predominates in its lowest $(+2)$ oxidation state (Fernando et al. 2010). Excess Mn(II) is sequestered and detoxified in dermal tissues of these plants (Fernando et al. 2013), although there is no clear explanation for detoxification in these tissues. We assume that, in contrast to the strong absorption of Mn by $\mathrm{Mn}$ hyperaccumulating plants, $S$. salsa Pall. might survive by the formation of iron and manganese oxides on its surface to reduce the harshness of excess $\mathrm{Mn}$ and to prevent the uptake of other heavy metals from saline and contaminated soils. Numerous studies have shown that S. salsa is an effective phytoremediation of salt marshes by reducing toxic metal levels from saline soils (Brown et al. 1999; Li et al. 2011). This process might be facilitated by the formation of Mn plaques on the surface of the plants, probably in combination with the activity of endophytic bacteria. These findings improve our understanding of the organic geochemistry in salt marshes and provided new insights into the cofunctions of microbes and plants in this process.

As indicated in the XRD and SAED patterns, the biogenic Mn oxides produced by the two endophytic strains differ significantly: birnessite $\left(\mathrm{MnO}_{2}\right)$ and rhodochrosite $\left(\mathrm{MnCO}_{3}\right)$ are produced by the endophytic $P$. eucrina SS01, while the bixbyite-like mineral $\left(\mathrm{Mn}_{2} \mathrm{O}_{3}\right)$ and $\mathrm{MnCO}_{3}$ are formed by $P$. composti $\mathrm{SS} 02$. These results imply that diverse mechanisms of $\mathrm{Mn}$ oxidation are involved in endophytic bacteria. So far, microbially mediated $\mathrm{Mn}$ (II) oxidation processes have 
mainly been studied in four typical marine strains, Roseobacter sp. AzwK-3b, Leptothrix discophora strain SS-1, Bacillus sp. strain G-1, and Pseudomonas putida strains MnB1 and GB-1 (Andeer et al. 2015; Corstjens et al. 1997; Dick et al. 2008; Geszvain et al. 2013). The primary Mn oxides produced by these bacteria were exclusively hexagonal birnessite with the presence of $\mathrm{MnO}_{2}$. Other forms of $\mathrm{Mn}$ oxides have rarely been studied, whereas a low-valence biogenic Mn oxide, $\mathrm{Mn}_{2} \mathrm{O}_{3}$, has been reported in two strains, Acinetobacter sp. and Bacillus CUA (Hosseinkhani and Emtiazi 2011; Zhang et al. 2015c).

We suggest the existence of various underlying $\mathrm{Mn}$ oxidation mechanisms for the two endophytic bacteria. The effects of the chemicals described in this work revealed that Mn-oxidizing activities are a correlated with ROS in both strains. However, superoxide appears to be associated with the formation of $\mathrm{MnO}_{2}$ by $P$. eucrina $\mathrm{SS} 01$, whereas superoxide was not detected in $P$. composti SS02. Catalase was identified in the $\mathrm{Mn}-$ oxidation active part in strain SS01, while catalaseperoxidase was found in strain SS02, which is consistent with the positive ABTS results for strain $\mathrm{SS} 02$ and the negative results for strain SS01. Since heavy metals generate ROS, leading to oxidative stress (Pinto et al. 2003), the induction of these hydrogen peroxidedetoxifying enzymes might be a physiological response to oxidative stress in the cells of these endophytic bacteria.

In this paper, we show the appearance of Mn oxides as plaques on the surface and in the pith of a wetland plant, S. salsa Pall. Two endophytic bacterial strains capable of oxidizing $\mathrm{Mn}$ (II) were isolated from these plants. Laboratory cultivation of $S$. salsa Pall. and the two isolates showed enhanced precipitation of Mn oxides on the plant roots, possibly serving as an oxidant of heavy metals and pollutants and as a scavenger of trace nutrients to sustain the growth of $S$. salsa plants in saline and heavy metal-contaminated wetlands. The chemical compositions of Mn were different for the two strains, and we suggest the presence of ROS-related pathways for Mn oxidation. The results of our study deepen our understanding of the molecular mechanisms in the plant-endophyte symbiosis in biogeochemical Mn cycling.

Acknowledgements The authors thank Dr. Liang Zhang (Shandong Normal University) for the help of SEM-EDX data analyses; Dr. Xuejie Zhang (Shandong Normal University) for the suggestion of plant dissections; Mr. Liyan Wang (Shandong University) for TEM imaging of the strains.

Funding This work was supported by the National Natural Science Foundation of China (Grant No. 31640002), the Natural Science Foundation of Shandong Province (Grant No. ZR2015JL013), the China Postdoctoral Science Foundation (Grant No. 2016 M600551), and the International Postdoctoral Exchange Fellowship Program of China (Grant No. 20170058).

Open Access This article is distributed under the terms of the Creative Commons Attribution 4.0 International License (http:// creativecommons.org/licenses/by/4.0/), which permits unrestricted use, distribution, and reproduction in any medium, provided you give appropriate credit to the original author(s) and the source, provide a link to the Creative Commons license, and indicate if changes were made.

Publisher's note Springer Nature remains neutral with regard to jurisdictional claims in published maps and institutional affiliations.

\section{References}

Adams LF, Ghiorse WC (1986) Physiology and ultrastructure of Leptothrix discophora SS-1. Arch Microbiol 145:126-135

Altschul SF, Gish W, Miller W, Myers EW, Lipman DJ (1990) Basic local alignment search tool. J Mol Biol 215:403-410

Andeer PF, Learman DR, Mcilvin M, Dunn JA, Hansel CM (2015) Extracellular haem peroxidases mediate Mn(II) oxidation in a marine Roseobacter bacterium via superoxide production. Environ Microbiol 17:3925-3936

Anderson CR, Johnson HA, Caputo N, Davis RE, Torpey JW, Tebo BM (2009) Mn(II) oxidation is catalyzed by heme peroxidases in "Aurantimonas manganoxydans" strain SI85-9A1 and Erythrobacter sp. strain SD-21. Appl Environ Microbiol 75:4130-4138

Andrades-Moreno L, Del Castillo I, Parra R, Doukkali B, Redondo-Gómez S, Pérez-Palacios P, Caviedes MA, Pajuelo E, Rodríguez-Llorente ID (2014) Prospecting metal-resistant plant-growth promoting rhizobacteria for rhizoremediation of metal contaminated estuaries using Spartina densiflora. Environ Sci Pollut Res Int 21:37133721

Benner SG, Blowes DW, Gould WD, Herbert RB, Ptacek CJ (1999) Geochemistry of a permeable reactive barrier for metals and acid mine drainage. Environ Sci Technol 33: 2793-2799

Bohu T, Santelli CM, Akob DM, Neu TR, Ciobota V, Rösch P, Popp J, Nietzsche S, Küsel K (2015) Characterization of pH dependent $\mathrm{Mn}$ (II) oxidation strategies and formation of a bixbyite-like phase by Mesorhizobium australicum T-G1. Front Microbiol 6. https://doi.org/10.3389 /fmicb.2015.00734

Brown JJ, Glenn EP, Fitzsimmons KM, Smith SE (1999) Halophytes for the treatment of saline aquaculture effluent. Aquaculture 175:255-268 
Butterfield CN, Soldatova AV, Lee SW, Spiro TG, Tebo BM (2013) $\mathrm{Mn}(\mathrm{II}, \mathrm{III})$ oxidation and $\mathrm{MnO}_{2}$ mineralization by an expressed bacterial multicopper oxidase. Proc Natl Acad Sci U S A 110:11731-11735

Clement BG, Luther GW, Tebo BM (2009) Rapid, oxygendependent microbial $\mathrm{Mn}(\mathrm{II})$ oxidation kinetics at submicromolar oxygen concentrations in the Black Sea suboxic zone. Geochim Cosmochim Acta 73:1878-1889

Corstjens PLAM, De Vrind JPM, Goosen T, de Vrind-de Jong EW (1997) Identification and molecular analysis of the Leptothrix discophora SS-1 mofA gene, a gene putatively encoding a manganese-oxidizing protein with copper domains. Geomicrobiol J 14:91-108

Dick GJ, Torpey JW, Beveridge TJ, Tebo BM (2008) Direct identification of a bacterial manganese(II) oxidase, the multicopper oxidase MnxG, from spores of several different marine Bacillus species. Appl Environ Microbiol 74:15271534

El Gheriany IA, Bocioaga D, Hay AG, Ghiorse WC, Shuler ML, Lion LW (2009) Iron requirement for Mn(II) oxidation by Leptothrix discophora SS-1. Appl Environ Microbiol 75: 1229-1235

Fernando DR, Lynch JP (2015) Manganese phytotoxicity: new light on an old problem. Ann Bot 116:313-319

Fernando DR, Mizuno T, Woodrow IE, Baker AJ, Collins RN (2010) Characterization of foliar manganese (Mn) in $\mathrm{Mn}$ (hyper)accumulators using X-ray absorption spectroscopy. New Phytol 188:1014-1027

Fernando DR, Marshall A, Baker AJ, Mizuno T (2013) Microbeam methodologies as powerful tools in manganese hyperaccumulation research: present status and future directions. Front Plant Sci 4(319). https://doi.org/10.3389 /fpls.2013.00319

Geszvain K, McCarthy JK, Tebo BM (2013) Elimination of manganese(II,III) oxidation in Pseudomonas putida GB-1 by a double knockout of two putative multicopper oxidase genes. Appl Environ Microbiol 79:357-366

Godrant A, Rose AL, Sarthou G, Waite TD (2009) New method for the determination of extracellular production of superoxide by marine phytoplankton using the chemiluminescence probes MCLA and red-CLA. Limnol Oceanogr: Methods 7(10):682-692

Guo JR, Suo SS, Wang BS (2015) Sodium chloride improves seed vigour of the euhalophyte Suaeda salsa. Seed Sci Res 25: 335-344

Guo JR, Li YD, Han GL, Song J, Wang BS (2018) NaCl markedly improved the reproductive capacity of the euhalophyte Suaeda salsa. Funct Plant Biol 45:350-361

Hansel CM, Zeiner CA, Santelli CM, Webb SM (2012) Mn(II) oxidation by an ascomycete fungus is linked to superoxide production during asexual reproduction. Proc Natl Acad Sci U S A 109:12621-12625

Hosseinkhani B, Emtiazi G (2011) Synthesis and characterization of a novel extracellular biogenic manganese oxide (bixbyitelike $\mathrm{Mn}_{2} \mathrm{O}_{3}$ ) nanoparticle by isolated Acinetobacter sp. Curr Microbiol 63:300-305

Jung WK, Schweisfurth R (1979) Manganese oxidation by an intracellular protein of a Pseudomonas species. Z Allg Mikrobiol 19:107-115

Khan N, Seshadri B, Bolan N, Saint CP, Kirkham MB, Chowdhury S, Yamaguchi N, Lee DY, Li G, Kunhikrishnan
A, Qi F, Karunanithi R, Qiu R, Zhu YG, Syu CH (2016) Root iron plaque on wetland plants as a dynamic pool of nutrients and contaminants. Adv Agron 138:1-96

Kim OS, Cho YJ, Lee K, Yoon SH, Kim M, Na H, Park SC, Jeon YS, Lee JH, Yi H, Won S, Chun J (2012) Introducing EzTaxon-e: a prokaryotic 16S rRNA gene sequence database with phylotypes that represent uncultured species. Int J Syst Evol Microbiol 62:716-721

Kimura M (1980) A simple method for estimating evolutionary rates of base substitutions through comparative studies of nucleotide sequences. J Mol Evol 16:111-120

Krämer U (2010) Metal hyperaccumulation in plants. Annu Rev Plant Biol 61:517-534

Krumbein WE, Altmann HJ (1973) A new method for the detection and enumeration of manganese oxidizing and reducing microorganisms. Helgol wiss Meeresunters 25:347-356

Larkin MA, Blackshields G, Brown NP, Chenna R, McGettigan PA, McWilliam H, Valentin F, Wallace IM, Wilm A, Lopez R, Thompson JD, Gibson TJ, Higgins DG (2007) Clustal W and Clustal X version 2.0. Bioinformatics 23:2947-2948

Learman DR, Voelker BM, Vazquez-Rodriguez AI, Hansel CM (2011) Formation of manganese oxides by bacterially generated superoxide. Nat Geosci 4:95-98

Learman DR, Voelker BM, Madden AS, Hansel CM (2013) Constraints on superoxide mediated formation of manganese oxides. Front Microbiol 4. https://doi.org/10.3389 /fmicb.2013.00262

Li X, Zhang XD, Song J, Fan H, Feng G, Wang BS (2011) Accumulation of ions during seed development under controlled saline conditions of two Suaeda salsa populations is related to their adaptation to saline environments. Plant Soil 341:99-107

Li X, Liu Y, Chen M, Song YP, Song J, Wang BS, Feng G (2012) Relationships between ion and chlorophyll accumulation in seeds and adaptation to saline environments in Suaeda salsa populations. Plant Biosyst 146:142-149

Liu QQ, Liu RR, Ma YC, Song J (2018) Physiological and molecular evidence for $\mathrm{Na}+$ and cl- exclusion in the roots of two Suaeda salsa populations. Aquat Bot 146:1-7

Mendelssohn IA, Postek MT (1982) Elemental analysis of deposits on the roots of Spartina alterniflora Loisel. Am J Bot 69:904-912

Michalak I, Chojnacka K, Marycz K (2011) Using ICP-OES and SEM-EDX in biosorption studies. Microchim Acta 172:6574

Minibayeva FV, Gordon LK, Kolesnikov OP, Chasov AV (2001) Role of extracellular peroxidase in the superoxide production by wheat root cells. Protoplasma 217:125-128

Miyata N, Tani Y, Maruo K, Tsuno H, Sakata M, Iwahori K (2006) Manganese (IV) oxide production by Acremonium sp. strain KR21-2 and extracellular Mn(II) oxidase activity. App1 Environ Microbiol 72:6467-6473

Pinto E, Sigaud-kutner TCS, Leitão MAS, Okamoto OK, Morse D, Colepicolo P (2003) Heavy metal-induced oxidative stress in algae. J Phycol 39:1008-1018

Saitou N, Nei M (1987) The neighbor-joining method: a new method for reconstructing phylogenetic trees. Mol Biol Evol 4:406-425

Soldatova AV, Butterfield C, Oyerinde OF, Tebo BM, Spiro TG (2012) Multicopper oxidase involvement in both Mn(II) and 
$\mathrm{Mn}$ (III) oxidation during bacterial formation of $\mathrm{MnO}_{2}$. J Biol Inorg Chem 17:1151-1158

Song J, Wang B (2015) Using euhalophytes to understand salt tolerance and to develop saline agriculture: Suaeda salsa as a promising model. Ann Bot 115:541-553

Spiro TG, Bargar JR, Sposito G, Tebo BM (2009) Bacteriogenic manganese oxides. Acc Chem Res 43:2-9

Su J, Bao P, Bai T, Deng L, Wu H, Liu F, He J (2013) CotA, a multicopper oxidase from Bacillus pumilus WH4, exhibits manganese-oxidase activity. PLoS One 8:e60573. https://doi. org/10.1371/journal.pone.0060573

Sui N, Tian SS, Wang WQ, Wang MJ, Fan H (2017) Overexpression of glycerol-3-phosphate acyltransferase from Suaeda salsa improves salt tolerance in Arabidopsis. Front Plant Sci 8. https://doi.org/10.3389/fpls.2017.01337

Sun WG, Gan ZT, Sun ZG, Li LL, Sun JK, Sun WL, Mou XJ, Wang LL (2013) Spatial distribution characteristics of Fe and Mn contents in the new-born coastal marshes in the Yellow River estuary. Huan Jing Ke Xue 34:4411-4419 In Chinese

Sundby B, Vale C, Cacador I, Catarino F (1998) Metal-rich concretions on the roots of salt marsh plants: mechanism and rate of formation. Limnol Oceanogr 43:245-252

Tamura K, Stecher G, Peterson D, Filipski A, Kumar S (2013) MEGA6: molecular evolutionary genetics analysis version 6.0. Mol Biol Evol 30:2725-2729

Tebo BM, Johnson HA, Mccarthy JK, Templeton AS (2005) Geomicrobiology of manganese (II) oxidation. Trends Microbiol 13:421-428

Tsuji K, Asayama T, Shiraki N, Inoue S, Okuda E, Hayashi C, Nishida K, Hasegawa H, Harada E (2017) Mn accumulation in a submerged plant Egeria densa (Hydrocharitaceae) is mediated by epiphytic bacteria. Plant Cell Environ 40: 1163-1173

Vale C, Catarino F, Cortesao C, Cacador M (1990) Presence of metal-rich rhizoconcretions on the roots of Spartina maritima from the salt marshes of the Tagus estuary, Portugal. Sci Total Environ 97/98:617-626

Vinogradov AD, Grivennikova VG (2005) Generation of superoxide-radical by the NADH: ubiquinone oxidoreductase of heart mitochondria. Biochemistry (Mosc) 70:120-127

Wang FX, Xu YG, Wang S, Shi WW, Liu R, Feng G, Song J (2015) Salinity affects production and salt tolerance of dimorphic seeds of Suaeda salsa. Plant Physiol Bioc 95:41-48
Wani ZA, Ashraf N, Mohiuddin T, Riyaz-Ul-Hassan S (2015) Plant-endophyte symbiosis, an ecological perspective. Appl Microbiol Biotechnol 99:2955-2965

Webb SM, Dick GJ, Bargar JR, Tebo BM (2005) Evidence for the presence of $\mathrm{Mn}(\mathrm{III})$ intermediates in the bacterial oxidation of Mn(II). Proc Natl Acad Sci U S A 102:5558-5563

Weis JS, Weis P (2004) Metal uptake, transport and release by wetland plants: implications for phytoremediation and restoration. Environ Int 30:685-700

Wu HF, Liu XL, Zhao JM, Yu JB (2012) Toxicological responses in halophyte Suaeda salsa to mercury under environmentally relevant salinity. Ecotoxic Environ Safe 85:64-71

Yamaji K, Nagata S, Haruma T, Ohnuki T, Kozaki T, Watanabe N, Nanba K (2016) Root endophytic bacteria of a $137 \mathrm{Cs}$ and $\mathrm{Mn}$ accumulator plant, Eleutherococcus sciadophylloides, increase $137 \mathrm{Cs}$ and $\mathrm{Mn}$ desorption in the soil. J Environ Radioactiv 153:112-119

Zhang WH, He LY, Wang Q, Sheng XF (2015a) Inoculation with endophytic Bacillus megaterium 1Y31 increases $\mathrm{Mn}$ accumulation and induces the growth and energy metabolism-related differentially-expressed proteome in $\mathrm{Mn}$ hyperaccumulator hybrid pennisetum. J Hazard Mater 30:513-521

Zhang WH, Chen W, He LY, Wang Q, Sheng XF (2015b) Characterization of Mn-resistant endophytic bacteria from Mn-hyperaccumulator Phytolacca americana and their impact on $\mathrm{Mn}$ accumulation of hybrid penisetum. Ecotoxic Environ Safe 120:369-376

Zhang Z, Lai J, Yin H, Feng X, Tan W, Liu F (2015c) Absorption mechanisms of $\mathrm{Cu}^{2+}$ on a biogenic bixbyite-like $\mathrm{Mn}_{2} \mathrm{O}_{3}$ produced by Bacillus CUA isolated from soil. Geochem T 16(5):5. https://doi.org/10.1186/s12932-015-0020-6

Zhang Z, Zhang Z, Chen H, Liu J, Liu C, Ni H, Zhao C, Ali M, Liu F, Li L (2015d) Surface Mn(II) oxidation actuated by a multicopper oxidase in a soil bacterium leads to the formation of manganese oxide minerals. Sci Rep 5(10895). https://doi. org/10.1038/srep10895

Zhou JC, Fu TT, Sui N, Guo JR, Feng G, Fan JL, Song J (2016) The role of salinity in seed maturation of the euhalophyte Suaeda salsa. Plant Biosyst 150:83-90 